\title{
Global Financial Reporting
}




\section{Global Financial Reporting}

JOHN FLOWER

with Gabi Ebbers 


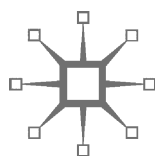

(C) John Flower 2002

Softcover reprint of the hardcover 1st edition 2002 978-0-333-97696-8

All rights reserved. No reproduction, copy or transmission of this publication may be made without written permission.

No paragraph of this publication may be reproduced, copied or transmitted save with written permission or in accordance with the provisions of the Copyright, Designs and Patents Act 1988, or under the terms of any licence permitting limited copying issued by the Copyright Licensing Agency, 90 Tottenham Court Road, London W1T 4LP.

Any person who does any unauthorized act in relation to this publication may be liable to criminal prosecution and civil claims for damages.

The authors have asserted their rights to be identified as the authors of this work in accordance with the Copyright, Designs and Patents Act 1988.

First published 2002 by

PALGRAVE

Houndmills, Basingstoke, Hampshire RG21 6XS and

175 Fifth Avenue, New York, N.Y. 10010

Companies and representatives throughout the world

PALGRAVE is the new global academic imprint of

St. Martin's Press LLC Scholarly and Reference Division and Palgrave Publishers Ltd (formerly Macmillan Press Ltd).

ISBN 978-0-333-79477-7

DOI 10.1007/978-1-137-10538-7

This book is printed on paper suitable for recycling and made from fully managed and sustained forest sources. Logging, pulping and manufacturing processes are expected to conform to the environmental regulations of the country of origin.

A catalogue record for this book is available from the British Library. 


\section{Contents}

List of Exhibits

Xvii

Preface

xxi

Acknowledgements

xxiii

List of Abbreviations

$\mathrm{XXV}$

\section{part one}

BACKGROUND

1 Globalization 3

1.1 Why study global financial reporting? 3

1.2 The globalization of the world economy 4

1.3 International trade 5

$\begin{array}{lll}1.4 & \text { Cross border investment } & 7\end{array}$

$\begin{array}{lll}\text { 1.4.1 } & \text { Foreign direct investment } & 7\end{array}$

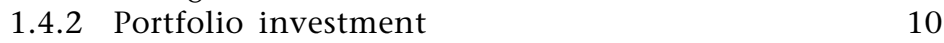

$\begin{array}{lll}1.5 & \text { The multinational enterprises } & 11\end{array}$

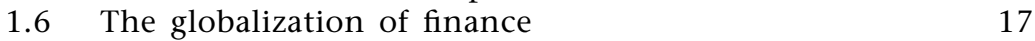

1.7 The financial reporting of the multinational enterprises 19

1.8 The Pentad 20

1.9 The rest of the book 21

1.10 The use of the Internet 22

Annex: Useful internet addresses $\quad 25$

2 The Causes of Diversity 27

$\begin{array}{lll}2.1 & \text { The contingent theory of accounting } & 27\end{array}$

2.2 The factors that shape financial reporting 28

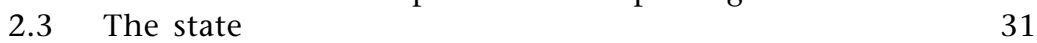

2.3.1 The political system 31

$\begin{array}{lll}2.3 .2 \text { Law } & 33\end{array}$

2.3.3 Taxation 34

2.3.4 The regulation of dividends and the
maintenance of the corporation's capital

2.3.5 Conclusion: the dominating influence of the state 38

2.4 The corporate financing system 38

$\begin{array}{lll}2.4 .1 & \text { The capital market } & 39\end{array}$ 
2.4.2 Direct provision of finance 41

2.4.3 The form of financing: equity versus debt 42

2.4.4 The influence of finance on financial reporting 43

2.5 The accountancy profession 44

2.6 Environmental factors 48

2.6.1 Other interested parties 48

2.6.2 Accounting theorists 49

$\begin{array}{ll}2.6 .3 & \text { Inflation } \\ 2.6 .4 & \text { Coloniaism }\end{array}$

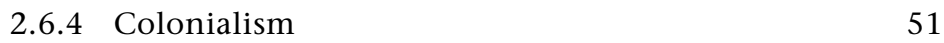

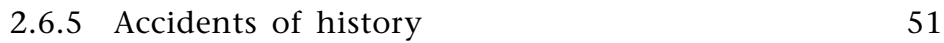

2.6.6 Other environmental factors 52

2.7 Culture 52

2.8 Synthesis: the Anglo Saxons versus the rest of the world 56

2.9 Conclusions 62

\section{Regulation}

3.1 Why are rules necessary? $\quad 67$

$\begin{array}{lll}3.1 .1 & \text { Preparers versus users } & 67\end{array}$

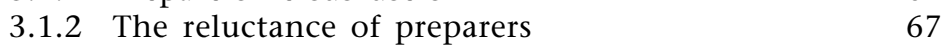

3.1.3 The information needs of users 68

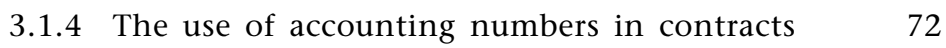

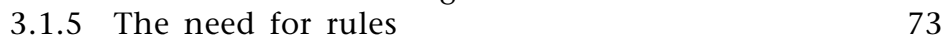

$\begin{array}{ll}3.2 & \text { The role of the government } \\ 3.2 .15\end{array}$

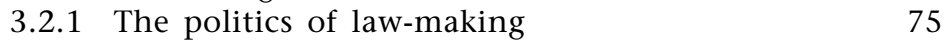

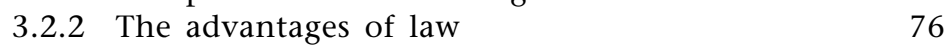

3.2.3 The need for additional rules $\quad 76$

$\begin{array}{lll}3.3 & \text { The hierarchy of rules } & 77\end{array}$

$\begin{array}{lll}3.3 .1 & \text { Law } & 79\end{array}$

3.3.2 The second level: delegated legislation
and court judgements

3.3.3 The lower levels of the hierarchy 80

3.4 The national regulatory system 82

\section{part two}

$\begin{array}{ll}\text { COUNTRY STUDIES } & 87\end{array}$

$4 \quad$ Britain $\quad 89$

W.1 Why Britain is important for the student of
financial reporting

4.2 The origins of British financial reporting 90

4.3 The separation of control from ownership 91

4.4 Britain's institutional framework 93

$\begin{array}{lll}4.4 .1 & \text { The state } & 93\end{array}$

$\begin{array}{ll}4.4 .2 \text { Taxation } & 94\end{array}$

4.4.3 The corporate financing system 96

$\begin{array}{ll}\text { 4.4.4 The accountancy profession } & 97\end{array}$

$\begin{array}{lll}4.5 & \text { The British regulatory system } & 101\end{array}$ 
4.5.1 A model of the British regulatory system

4.5.2 The Companies Act

4.5.3 Accounting standards

103

4.5.4 Stock exchange listing rules

105

4.5.5 Professional rules

106

4.5.6 Accepted practice: 'true and fair view' 106

4.5.7 Synthesis: UK GAAP

108

4.6 The principal characteristics of British financial reporting

109

\section{The USA}

5.1 The importance of the USA

5.2 The origins of American financial reporting 114

5.3 The institutional framework 117

$\begin{array}{lll}5.3 .1 & \text { The state } & 117\end{array}$

5.3.2 Taxation 118

5.3.3 The corporate financing system 119

$\begin{array}{ll}\text { 5.3.4 The accountancy profession } & 121\end{array}$

$\begin{array}{ll}\text { 5.3.5 The universities } & 123\end{array}$

$\begin{array}{ll}5.4 \text { The American regulatory system } & 125\end{array}$

$\begin{array}{ll}\text { 5.4.1 The government } & 125\end{array}$

5.4.2 The SEC: the Securities and Exchange
Commission

5.4.3 The FASB: the Financial Accounting Standards Board $\quad 127$

5.4.4 Congress $v$. the SEC $v$. the FASB 130

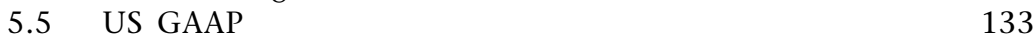
5.6 The essential characteristics of American financial
reporting

6 France

6.1 The importance of France for the student of financial reporting

6.2 The origins of French financial reporting 140

$\begin{array}{ll}\text { 6.3 The French institutional framework } & 142\end{array}$

6.3.1 The state 142

6.3.2 Law: the Commercial Code 143

6.3.3 Taxation 143

6.3.4 The corporate financing system 145

6.3.5 The accountancy profession 147

6.4 The French regulatory system 149

$\begin{array}{lll}6.4 .1 & \text { Laws and decrees } & 149\end{array}$

6.4.2 The Comité de Réglementation Comptable (CRC) 150

6.4.3 The Plan Comptable Général (PCG) 150

6.4.41 The Conseil National de la Comptabilité (CNC) 153

6.4.5 The Commission des Opérations de Bourse (COB) 154

6.4.6 Recommendations of the accountancy profession 154

6.5 The future of French financial reporting 154 
7 Germany

7.1 Why Germany is important for the study of global financial reporting

7.2 The origins of German financial reporting 159

7.3 The German institutional framework 160

7.3.1 The state 160

7.3.2 Law: the Commercial Code 161

7.3.3 Grundsätze ordnungsmässiger Buchführung (GoB) 162

7.3.4 Taxation 164

7.3.5 The corporate financing system 166

7.3.6 The accountancy profession 168

$\begin{array}{lll}7.4 & \text { The German regulatory system } & 170\end{array}$

7.4.1 Law 170

7.4.2 GoB: the market for interpretations 171

$\begin{array}{lll}7.4 .3 & \text { Standards } & 171\end{array}$

7.5 The future of German financial reporting 172

8 Japan 175

$\begin{array}{ll}8.1 & \text { The importance of Japan } \\ 8.2 & 175\end{array}$

$\begin{array}{lll}8.2 & \text { History } & 176\end{array}$

8.2.1 The first accounting revolution, 1853-99 176

8.2.2 The second accounting revolution, 1945-49 178

$\begin{array}{lll}8.3 & \text { The Japanese institutional framework } & 178\end{array}$

8.3.1 The state 178

8.3.2 Taxation 179

8.3.3 The corporate financing system 180

8.3.4 The accountancy profession 180

8.4 The Japanese regulatory system: the triangular system 181

8.4.1 The Commercial Code (CC) 183

8.4.2 The Securities and Exchange Law (SEL) 183

8.4.3 The tax law 184

8.4.4 The functioning of the 'triangular system' 184

8.4.5 The Business Accounting Deliberation Council (BADC) 186

8.4.6 Reform of the BADC 188

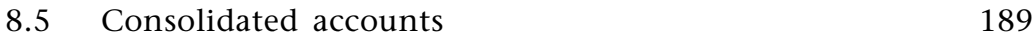

8.6 The financial statements of Japanese MNEs 190

$\begin{array}{lll}8.7 \text { Conclusions } & 194\end{array}$

9 The European Union 198

9.1 The European Union: Introduction 199

9.2 The EU's interest in financial reporting 201

9.2.1 The common market 201

$\begin{array}{ll}\text { 9.2.2 The protection of shareholders } & 202\end{array}$

9.2.3 'The level playing field' 202

9.2.4 Harmonization before relevance 203 
9.3 The EU's structure

9.3.1 The legislative function 204

9.3.2 The executive function 204

9.3.3 The judicial function 205

9.4 The EU's harmonization programme 205

$\begin{array}{ll}\text { 9.4.1 The role of EU directives } & 205\end{array}$

9.4.2 The Fourth Directive: the accounts of the individual enterprise 206

$\begin{array}{lll}9.4 .3 & \text { Options } & 207\end{array}$

9.4.4 The Seventh Directive: the consolidated accounts 207

9.5 The impact of the Fourth and Seventh Directives 208

9.6 The EU's limitations as a rule maker 211

\section{part three}

THE INTERNATIONAL ACCOUNTING STANDARDS

10 The Global Rule-Makers

10.1 The problems facing the multinational enterprises

10.1.1 Internal management

10.1.2 External financing

10.2 The case of Daimler Benz

10.3 The need for a single set of rules

10.3.1 The advantages of uniformity

10.3.2 Uniformity versus relevance

10.4 The possible global rule makers

10.5 A single country: the USA

10.6 A group of countries: the European Union

10.7 International organizations

10.7.1 The United Nations (UN)

10.7.2 The Organisation for Economic Cooperation

10.7.3 The International Accounting Standards Board (IASB)

10.8 The IASB versus the SEC

11 The IASB: its Origins and Structure

11.1 The IASC's origins and objectives

11.2 The IASC's structure

11.2.1 The Committee

11.2.2 The Board's powers

11.2.3 The Board's composition

11.2.4 Other elements of the IASC's organization

11.3 Evaluation of the IASC's structure 
11.4 Proposals for change

11.5 The IASB's constitution 249

11.5.1 Title 249

11.5.2 The IASB's objectives $\quad 249$

11.5.3 The IASB's structure 250

11.6 The composition of the new Board 253

11.7 Comments on the IASB's structure 256

$\begin{array}{ll}11.8 \text { Conclusions } & 260\end{array}$

12 The IASB: Its Standards 263

12.1 The international accounting standards 263

12.2 The authority of IAS 265

12.3 Recent developments 269

12.3.1 The agreement between the IASC and the IOSCO

12.3.2 The EU's new accounting strategy 271

12.3.3 Implications for the acceptability of the IASs

272

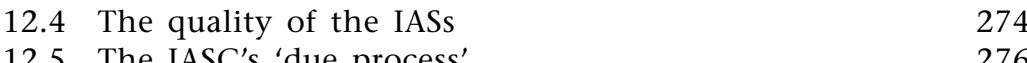

12.5 The IASC's 'due process' 276

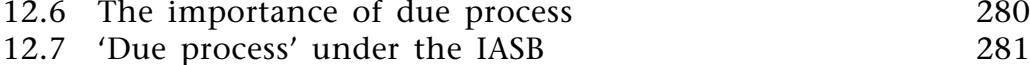

13 The IASB's Framework 284

13.1 Conceptual frameworks in general 284

13.1.1 Examples of frameworks 284

13.1.2 Definition and characteristics 285

13.1.3 The benefits of a conceptual framework 287

13.2 The purposes of the IASB's Framework 288

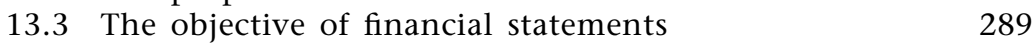

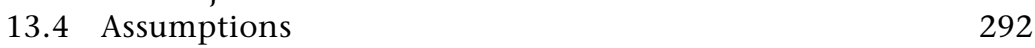

13.5 Qualitative characteristics of financial statements 293

13.5.1 Materiality 294

13.5.2 Relevance $\quad 294$

13.5.3 Reliability 296

13.6 Constraints on the value of information 298

13.7 The elements of financial statements 300

13.7.1 Definition 302

13.7.2 Recognition $\quad 304$

13.7.3 Measurement 305

13.7.4 Concepts of capital maintenance 305

13.8 Evaluation of the IASB's Framework 305

Annex: The IASB's Framework for the Preparation and

Presentation of Financial Statements 


\section{The Anatomy of an International Accounting}

\section{Standard: IAS 1}

14.1 The structure of an international accounting standard

14.2 The text of the standard

14.3 Compliance with IAS

14.4 Principles to be followed when there is no relevant IAS

14.5 The 'present fairly' rule

14.6 The components of a set of financial statements

14.6.1 The balance sheet

14.6.2 The income statement

14.6.3 The cash flow statement

14.6.4 The statement of changes in equity 340

14.6.5 The notes to the accounts

\section{part four}

\section{THE FINANCIAL STATEMENTS}

\section{The Balance Sheet I: Assets}

15.1 The balance sheet versus the income statement

15.1.1 The primacy of the balance sheet

15.1.2 The matching principle

15.2 The format of the balance sheet

15.3 Assets in the balance sheet: the three tests 353

15.3.1 Definition 353

15.3.2 Recognition 354

15.3.3 Measurement 355

15.4 The principal categories of assets 355

15.4.1 Inventories 355

15.4.2 Plant, property and equipment 357

15.4.3 Intangible assets 359

15.4.4 Prepayments and other accruals 360

15.4.5 The dominance of historical cost 360

15.4.6 Financial assets 361

15.4.7 Investment property 362

15.4.8 Agricultural assets 362

15.4.9 Assets not covered by IASs 363

15.5 Depreciation and amortization 363

15.6 Impairment 366

15.6.1 The basic rule 366

15.6.2 How to measure 'value in use' 367

15.6.3 Criticisms of 'value in use' 368

15.6.4 The 'hotch-potch' of valuation rules 369

15.6.5 When assets must be tested for impairment $\quad 370$

15.6.6 The IASB compared with the FASB 371

15.7 The assets of the largest MNEs 372

15.8 Comparative analysis of asset valuation methods 374 
15.8.1 Non-current tangible assets

16 The Balance Sheet II: Liabilities and Equity 384

16.1 The form of the balance sheet 384

16.2 The enterprise model versus the proprietary model 385

16.2.1 The proprietary model 385

16.2.2 The enterprise model 388

16.2.3 The dominance of the proprietary model $\quad 389$

$\begin{array}{lll}16.3 & \text { Liabilities } & 389\end{array}$

16.4 IAS 37: provisions 390

16.4.1 Definition of a provision 390

16.4.2 The recognition of a provision 391

16.4.3 The problem of the provision for future expenses 394

16.4.4 The measurement of provisions 397

16.5 Other liabilities: accruals 400

16.6 The equity of corporations 402

16.6.1 Contributed capital 402

16.6.2 Reserves 404

16.6.3 Dividends 406

16.6.4 Treasury shares 406

16.7 The distinction between equity and liabilities 407

16.7.1 The legal approach 407

16.7.2 The economics approach 408

16.7.3 Preference shares 409

16.7.4 Convertible loans 410

16.7.5 The IASB's rules for preference shares and
convertible loans

16.8 The equity and liabilities of the largest MNEs 415

16.9 Examples 418

16.9.1 USA: General Motors 418

16.9.2 UK: BP Amoco PLC 419

16.9.3 Japan: Sony 421

16.9.4 France: Alcatel 422

16.9.5 Germany: Volkswagen 423

17 The Income Statement $\quad \mathbf{4 2 7}$

17.1 The recognition of revenue 428

17.2 The presentation of income and expenses 431

17.2.1 The needs of users 431

17.2.2 The format of the income statement 432

17.2.3 Revenue: total sales or total output? 434

17.2.4 The classification of expenses 436

17.2.5 The classification of expenses by nature 436

17.2.6 The classification of expenses by function $\quad 437$

17.2.7 Extraordinary items and exceptional items 438 
17.2.8 Discontinuing operations

17.2.9 Segment reporting 443

17.2.10 Conclusions 449

17.3 The measurement of profit 450

17.3.1 Gains and losses taken direct to equity 450

$\begin{array}{ll}\text { 17.3.2 Prior period adjustments } & 451\end{array}$

17.4 Concepts of profit 453

17.4.1 The comprehensive income concept 453

17.4.2 The current operating performance concept 454

17.4.3 Evaluation of the two concepts 455

17.5 The statement of total recognised gains and losses
(STRGL)

17.5.1 The STRGL according to IAS 1

17.5.2 The STRGL: a statement of performance? 457

17.5.3 The statement of changes in equity 461

17.6 Reporting financial performance: proposals for change 467

$\begin{array}{lll}17.7 & \text { Earnings per share } & 470\end{array}$

\section{The Cash Flow Statement 474}

18.1 The cash flow statement compared with the income statement

18.2 The reliability of the cash flow statement 475

18.3 The relevance of the cash flow statement 476

18.3.1 The value of the enterprise 477

18.3.2 The solvency of the enterprise 478

$\begin{array}{lll}18.4 & \text { IAS } 7 & 479\end{array}$

18.4.1 The definition of cash 480

18.4.2 The classification of cash flows 480

18.4.3 Practical problems of classification 482

18.4.4 The classification of interest and dividends 482

18.5 The form of the cash flow statement 484

18.6 The reconciliation with the balance sheet 487

18.7 Cash flows of subsidiaries, joint ventures and
associated enterprises

$\begin{array}{lll}18.8 & \text { Non-cash transactions } & 489\end{array}$

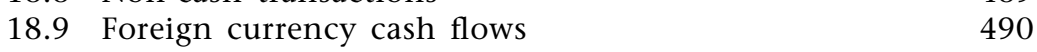

18.10 Comparative analysis $\quad 493$

18.10.1 Laws and standards 493

18.10.2 The direct method versus the indirect method 494

18.10.3 Definition of cash and cash equivalents 495

18.10.4 Which enterprises are required to prepare
a cash flow statement?

$\begin{array}{lll}\text { 18.10.5 Classification } & 497\end{array}$

18.11 Examples from published accounts $\quad 497$

$\begin{array}{lll}\text { 18.11.1 USA } & 497\end{array}$

$\begin{array}{lll}18.11 .2 & \text { Britain } & 499\end{array}$

$\begin{array}{lll}18.11 .3 & \text { France } & 500\end{array}$ 
19 The Consolidated Accounts

19.1 The economic importance of groups 506

19.1.1 The Renault Group 506

19.1.2 Why large businesses are organized as groups 508

19.2 The individual accounts 509

19.2.1 Dividends 510

19.2.2 Tax 510

19.2.3 Liquidation 511

19.3 The consolidated accounts 513

19.4 The definition of the group 514

19.4.1 The parent company concept of the group 514

19.4.2 The economic entity concept 517

19.4.3 The definition of the group in law and practice 518

19.4.4 Excluded subsidiaries 524

19.5 The preparation of consolidated accounts 526

19.5.1 The basic principles $\quad 526$

19.5.2 Take-overs 527

19.5.3 Mergers 529

19.5.4 The attractions of the merger method 532

19.5.5 The acquisition method and the merger method in practice 534

19.5.6 A third possibility: the 'fresh-start' method 536

19.5.7 Proposals for change 537

19.6 The minority interest: equity or liability? 539

19.7 The partial members of the group 540

19.7.1 Joint ventures 541

19.7.2 Associates 542

19.7.3 Synthesis 543

\section{part five}

ISSUES

20 Intangible Assets $\quad 549$

20.1 The growth in the importance of intangible assets 549

20.2 The classification of intangible assets 551

20.3 Goodwill 552

20.3.1 The meaning of the accounting term 552

20.3.2 Internally generated goodwill 554

20.3.3 Acquired goodwill 555

20.4 Identifiable intangible assets 559

20.4.1 The general rules of IAS $38 \quad 559$

20.4.2 Acquired identifiable intangible assets 564

20.4.3 Internally generated identifiable intangible assets 565

20.4.4 Comparability of acquired and internally generated intangibles $\quad 567$

20.5 A functional classification of intangible assets 568

$\begin{array}{ll}\text { 20.5.1 Organizational capital } & 569\end{array}$ 
20.5.2 Customer capital $\quad 570$

20.5.3 Human capital $\quad 572$

20.6 Reporting of intangible assets in practice 573

20.6.1 Organizational capital: research and development

573

$\begin{array}{ll}\text { 20.6.2 Customer capital: brands } & 575\end{array}$

20.6.3 Human capital: professional sportsmen $\quad 577$

\section{Foreign Currency Translation}

21.1 The basic translation problem

21.2 The translation of transactions versus the translation of financial statements

21.3 The translation of transactions: the theory

21.3.2 The accrual principle versus the prudence principle

21.4 The translation of transactions: the rules 589

21.5 The translation of financial statements 589

21.6 The temporal method of translation 590

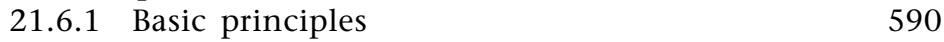

21.6.2 The Lorensen study and FAS $8 \quad 591$

21.6.3 The great debate on translation 591

21.7 Comparison of the two methods 592

21.8 The case for the temporal method 594

21.9 The case for the closing rate method 595

21.9.1 The parent's investment in the subsidiary 595

21.9.2 The income statement 596

21.10 The victory of the closing rate method: FAS 52

21.11 IAS $21 \quad 598$

21.12 The source of regulation: laws, standards, recommendations 600

$\begin{array}{ll}21.13 \text { Comparative country analysis } & 602\end{array}$

21.13.1 Foreign currency transactions $\quad 602$

21.13.2 Foreign financial statements $\quad 606$

$\begin{array}{ll}21.14 \text { Concluding remarks } & 611\end{array}$

22 Financial Instruments $\quad 615$

22.1 The fable of the two investment trusts 616

22.2 The three basic problems with financial assets 617

22.3 The IASC's search for a solution 618

22.4 The IASB's rules for financial instruments 620

22.4.1 Categories of financial assets and liabilities 621

22.4.2 Recognition of financial assets and liabilities 622

22.4.3 Measurement of financial assets and liabilities 622

22.4.4 The income of financial assets 626

22.4.5 Disclosure of financial assets and liabilities $\quad 628$

22.5 Risk analysis 628 
22.5.1 Risk categories

22.5.2 Disclosure of risks 630

22.6 Derivatives 630

22.6.1 Forward contracts 631

22.6.2 Options $\quad 632$

22.6.3 Swaps 633

22.6.4 The meaning of the term 'derivative' 633

22.6.5 The importance of derivatives 634

22.6.6 The inadequacy of present financial
reporting techniques

22.6.7 The IASB's rules for derivatives 638

$\begin{array}{lll}22.7 & \text { Hedging } & 639\end{array}$

22.7.1 What is 'hedging' 639

22.7.2 The problems for financial reporting 640

22.7.3 Why conventional accounting gets it wrong 641

22.7.4 Possible solutions 641

22.7.5 The IASB's rules for hedges 643

$\begin{array}{lll}22.8 & \text { Comparative analysis } & 644\end{array}$

22.8.1 USA 644

22.8.2 Japan 646

22.8.3 Britain $\quad 646$

$\begin{array}{ll}22.8 .4 & \text { Germany }\end{array}$

22.8.5 France 648

23 Global Disclosure $\quad 651$

23.1 Introduction 651

23.2 Disclosure instruments $\quad 654$

23.3 Disclosure and capital markets 657

23.4 The costs of disclosure $\quad 659$

$\begin{array}{ll}23.5 & \text { Reporting practices } \\ & 661\end{array}$

23.5.1 Example: DaimlerChrysler annual
report 1999 661

23.5.2 Example: SAP annual report $1999 \quad 664$

$\begin{array}{lll}23.6 \text { Conclusion } & 667\end{array}$

$\begin{array}{ll}\text { Index of Laws and Standards } & 671\end{array}$

Index $\quad 673$ 


\section{List of Exhibits}

1.1 Global merchandise exports and imports 5

1.2 Flows of foreign direct investment, $1999 \quad 8$

1.3 Stock of foreign direct investment, $1999 \quad 9$

$\begin{array}{lll}1.4 & \text { The world's top } 50 \text { multinational enterprises } & 14\end{array}$

$\begin{array}{lll}1.5 & \text { Forms of corporations } & 16\end{array}$

1.6 The top 100 MNEs: analysis of the country of the

$\begin{array}{lll}1.7 & \text { Analysis of the European MNEs in the top one hundred } 17\end{array}$

1.8 Cross-border transactions in bonds and shares as a $\begin{array}{ll}\text { percentage of GDP } & 18\end{array}$

1.9 Analysis of the shareholders of Aventis SA 19

2.1 The interplay of the environment, institutions and culture 29

2.2 The factors that influence financial reporting according to three leading textbooks $\quad 30$

2.3 Rates of tax on a corporation's profits 34

2.4 The stock exchanges of the world 40

2.5 The world's accountancy and audit profession 47

2.6 Hofstede's scores and rankings for selected countries 54

2.7 The relationship between Gray's 'accounting values' and Hofstede's cultural dimensions $\quad 55$

2.8 Synthesis of the major influences on financial reporting 57

2.9 Doupnik and Salter's classification of national $\begin{array}{ll}\text { accounting systems } & 59\end{array}$

2.10 The position of the clusters with regard to disclosure 60

3.1 The users of financial statements 68

$\begin{array}{lll}3.2 & \text { The hierarchy of rules } & 78\end{array}$

3.3 The quantitative importance of the various categories 83

4.1 The relentless growth of British Company Law 94

4.2 The British accountancy profession 98

4.3 The British system for the regulation of financial reporting 102

$\begin{array}{lll}5.1 & \text { Inventory valuations in published accounts } & 119\end{array}$

$\begin{array}{ll}5.2 & 123\end{array}$ 
5.3 The US system for the regulation of financial reporting 126

6.1 The size of the French accountancy profession 148

6.2 The French system for the regulation of financial reporting 151

$\begin{array}{lll}7.1 & \text { The German audit profession } & 169\end{array}$

7.2 The German system for the regulation of financial reporting 170

$\begin{array}{lll}8.1 & \text { The Japanese triangular system } & 182\end{array}$

$\begin{array}{lll}\text { 8.2 Important statements of the BADC } & 187\end{array}$

8.3 Cross shareholdings in the Sumitomo keiretsu 190

8.4 Fujitsu Ltd: reconciliation between the published accounts (Japanese GAAP) and IAS 193

9.1 The European Union: basic facts, $1998 \quad 199$

9.2 The relationship between the EU's rules and the
member state rules

$\begin{array}{lll}10.1 & \text { Daimler Benz reconciliation statement } 221\end{array}$

10.2 The financial reporting rules used by the top 50 MNEs 231

$\begin{array}{lll}11.1 & \text { The ISAC's structure } & 240\end{array}$

11.2 The membership of the ISAC's board, 1973-2001 242

$\begin{array}{lll}11.3 & \text { The ISAB's structure } & 251\end{array}$

$\begin{array}{ll}11.4 & \text { The members of the IASB } \\ 11.5 & 254\end{array}$

$\begin{array}{ll}11.5 & \text { The background of the new members } \\ 12.155\end{array}$

12.1 The International Accounting Standards at 30 June $2001 \quad 264$

12.2 The current status of IAS in 67 countries 266

12.3 The acceptability of IAS by the leading stock exchanges 267

12.4 The number of enterprises that use IAS 268

12.5 The development of an International Accounting Standard 277

$\begin{array}{lll}13.1 & \text { The needs of users } & 292\end{array}$

13.2 The qualitative characteristics of financial statements 295

13.3 The three conditions for reporting an element of the financial statements $\quad 301$

13.4 The IASB Framework definitions 302

15.1 The articulation of the balance sheet and the income statement

15.2 The balance sheet under the matching principle 350

15.3 Global Corp: balance sheet 352

15.4 Asset valuation methods specified in the IASs 356

15.5 The general rule for the reported value of an asset 367

$\begin{array}{ll}15.6 & \text { Application of the impairment test } 370\end{array}$

15.7 The structure of the assets' side of the balance sheet 373

15.8 Extract from the 1999 annual report of the Peninsular \& Oriental Steam Navigation Company 378

15.9 Extract from the 1999 annual report of General Motors 381

16.1 Four different ways to present the balance sheet 386

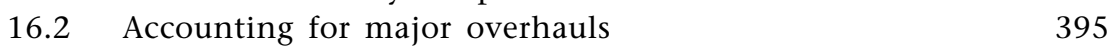


16.3 Example of the calculation of a provision: simple

16.4 Example of the calculation of a provision: complex

16.5 The legal approach versus the economics approach

16.6 An example of the reporting of convertible debt

16.7 The structure of the liabilities and equity side of the balance sheet

16.8 General Motors $1999 \quad 418$

16.9 Extract from BP Amoco's balance sheet, 31 December 1999420

16.10 Sony: balance sheet at 30 June 2000

16.11 Alcatel: consolidated balance sheet at 31 December 1999

16.12 Volkswagen Group: balance sheet at 31 December 1999423

17.1 Points of revenue recognition 429

17.2 The alternative formats for the income statement 433

17.3 EU Fourth Directive, article $24 \quad 434$

17.4 Fiat Group: statement of operations, 1999435

17.5 Volkswagen Group: statement of earnings for the year ended 31 December 1999

17.6 News Corporation Limited: extract from the profit and loss account for the year ended 30 June $1999 \quad 442$

17.7 Royal Dutch/Shell Group, 1999 annual report 448

17.8 Global Corp: statement of total recognized gains and losses 456

17.9 An example of recycling 460

17.10 Global Corp: statement of changes in equity for the year 2000

17.11 BP Amoco, annual report $1999 \quad 464$

17.12 General Motors: statement of stockholders' equity 466

17.13 The statement of financial performance according to the $\mathrm{G} 4+1$

17.14 Operating items versus other gains and losses 469

17.15 DaimlerChrysler: earnings per share (1999) 471

18.1 The relationship between the cash flow statement
and the income statement

18.2 Global Corp: cash flow statement, the direct method 485

18.3 Global Corp: cash flow statement, the indirect method 486

18.4 The South African subsidiary's bank account 491

18.5 The direct method versus the indirect method 495

18.6 The definition of cash and cash equivalents 496

18.7 General Electric Company and consolidated affiliates: year ended 31 December 1999

18.8 Cadbury Schweppes Group: cash flow statement for the 52 weeks ending 2 January 2000

18.9 Alcatel Group: consolidated statement of cash flows, $1999 \quad 501$

19.1 The structure of the Renault Group 507

19.2 The size of groups in the European automobile industry 509 
19.3 An example of the liquidation of a group

19.4 The definition of the group for consolidated accounts

19.5 An example of the economic entity concept of the group:

The Unilever Group

19.6 Implementation of the de facto control provisions of the Seventh Directive

19.7 Nissan: annual report for the year ended 31 March 2000

19.8 Alpha and Beta: the acquisition method compared with the merger method

19.9 Key figures in the consolidated accounts of the Alphabet Group

19.10 BP Amoco annual report $1998 \quad 535$

19.11 Comparison of the three methods: accounting treatment in the consolidated accounts

20.1 The classification of assets 552

20.2 The calculation of goodwill 553

20.3 Possible components of acquired goodwill 556

20.4 Intangible assets: their definition, recognition and initial measurement

20.5 Skandia's intellectual capital $\quad 569$

20.6 The twelve most valuable global brands 571

20.7 The research and development of European pharmaceutical firms

20.8 Tottenham Hotspur PLC: annual report, $1996 \quad 578$

21.1 The disappearing Brazilian loan 587

21.2 Don't count your chickens before they are hatched! 588

21.3 Comparison of the temporal method and the closing rate method

21.4 Analysis of the translation gain(loss) 594

21.5 The exchange rate used to translate foreign receivables and payables

21.6 The recognition of the translation gain on unsettled foreign receivables and payables

605

$\begin{array}{lll}22.1 & \text { The fable of the two investment trusts } & 616 \\ 22.2 & \text { Subsequent measurement of financial assets and liabilities } & 623\end{array}$

$\begin{array}{ll}22.3 & \text { Example of amortized historical cost }\end{array}$

22.4 Value of the forward foreign exchange contract and of the option

22.5 How to lose your shirt with a short sale

22.7 BP Amoco: fair values of financial assets and liabilities, 31 December 1999

23.1 Cadbury Schweppes: annual report, 1999 


\section{Preface}

The subject matter of this book is financial reporting at the global level, with particular emphasis on the larger multinational enterprises, such as the USA's General Electric, Japan's Toyota, Germany's DaimlerChrysler, France's Vivendi and Britain's BP Amoco. There are two commonly-accepted approaches to the study of financial reporting at the global level: the 'country approach' and the 'issues approach'. With the country approach the basic unit of study is the individual country. Through an examination of financial reporting as practised in various countries, the student gains an understanding not only of the accounts of enterprises from these countries but also of the richness and diversity of accounting throughout the world. The arguments in favour of the country approach may be summarised as follows:

Financial reporting is still basically regulated at the country level. Even the largest and most globally oriented of the 'global players' is obliged to follow national rules and standards when drawing up its financial statements. Among the advocates of the country approach are Walton, Haller and Raffournier who, in the preface to their textbook International Accounting (International Thompson Business Press, London, 1998), justify their position in the following terms:

We take the view that accounting in any one country at any one time represents the result of an evolution over many years. This evolution has taken place against a cultural backcloth which imbues each country's rules with many particularities, and institutions have been created which are unique in each country. We think therefore a holistic approach offers a more profound way of addressing international accounting differences.

The authors of the present book are basically in agreement with the position set out in this quotation. In particular, they consider that the present practice of financial reporting can only be fully understood with reference to its historical development and that the greater part of this 
historical development has taken place at the level of the individual country. In order to understand how financial reporting has reached its present position, then, an examination of the development at the country level is essential.

The first part of this book adopts the 'country approach'. Part One sets the scene with an analysis of the factors that cause national differences in financial reporting rules and practice; in Part Two the rules and practices of a number of countries are analysed, using a country-by-country approach, with one chapter per country.

However the greater part of the book does not adopt the country approach. In Part Two, only five countries are examined in detail. In most textbooks that adopt the country approach, many more countries are covered; for example Walton, Haller and Raffournier cover no less than twenty-two countries. The authors of the present book limit themselves to five countries for the following reasons:

(i) The five countries (USA, Japan, Germany, France and Britain) are the most important for the study of global financial reporting, as measured by most criteria: GNP, share of world trade, number of multinational enterprises and, most significantly, influence on the development of global financial reporting rules and practice.

(ii) The authors' aim is not to provide a treatise of financial reporting as practised in a large number of countries, but rather to analyse and explain financial reporting as practised at the global level. This can be done quite adequately through an examination of the five most important countries.

(iii) The authors believe that five is about the maximum number of countries that a student can study without becoming bored by the inevitable repetition and losing interest in the whole process.

In April 2001, an event occurred which is certain to have far-reaching consequences on the future development of financial reporting at the global level. The International Accounting Standards Board (IASB) took over from its predecessor, the IASC, the task of setting standards for the world. Undoubtedly the IASB will be an important new force in global financial reporting. Thus the whole of Part Three is given over to an exposition and analysis of this body, in effect adopting the 'country approach' to the examination of an international institution.

The alternative way to study financial reporting at the global level is to adopt the 'issues approach'; the breakdown of the subject is by topics and not by countries, the more important topics and issues being analysed globally. The authors believe that the 'issues approach' has certain advantages in presenting the complex and diverse material of global financial 
reporting. In particular there is less chance of the student losing interest through the repetition that inevitably accompanies the country approach. Furthermore the IASB's standards provide a very convenient framework for the exposition and analysis of the major issues on a global basis. In effect the increasing globalization of financial reporting (as evidenced in the enhanced role of the IASB) has reached the stage where the country approach is no longer sufficient. Hence the greater part of the book adopts the issues approach: Part Four considers the various elements of the financial statements and Part Five certain other issues, selected for their topical interest.

\section{TARGET READERSHIP}

The book is designed for final-year undergraduate and postgraduate courses in accounting and finance. The emphasis is on the 'why' and not the 'how' of accounting - to analyse and explain the practice of financial reporting at the global level, with particular reference to the financial statements of the larger multinational enterprises and to the standards of the International Accounting Standards Board. 


\section{Acknowledgements}

The authors would like to express their thanks to Professor Makoto Nakano of Hiitotsubashi University and Professor C. Richard Baker of the University of Massachusetts for guidance on the financial reporting of Japan and the United States, respectively. They also acknowledge the help given by Andrew Lymer of the University of Birmingham on matters relating to the Internet.

They also express their appreciation to the following enterprises which agreed that extracts from their financial statements should be included in the book:

Alcatel, Aventis, BASF, Bayer, BP Amoco, Cadbury Schweppes, DaimlerChrysler, FIAT Group, Ford Motor Company, Fujitsu, General Electric Company, General Motors, Henkel, News Corporation Ltd, Peninsular and Oriental Steam Navigation Company, Nissan, Peugeot, Roche, Royal Dutch/Shell Group, SAP, Skandia, Sony, TotalFinaElf, Tottenham Hotspur PLC, Toyota, VIAG, Vivendi, Volkswagen AG.

The authors and publishers would like to thank the following for permission to reproduce copyright material.

International Journal of Accounting, for Exhibits 2.9 and 2.10, from Doupnik and Salter, 'External environment, culture and accounting practice' 30(3). (C) 1995 Elsevier Science.

International Accounting Standards, Exposure Drafts, and other IASB publications are copyright of the International Accounting Standards Committee Foundation, including its International Accounting Standards Board. Please address copyright enquiries to: IASB Publications Department, 7th Floor, 166 Fleet Street, London EC4A 2DY, United Kingdom. Telephone: +44 (020) 7427-5927, Fax: +44 (020) 7353-0562, E-mail: iasb@iasb.org.uk, Internet: www.iasb.org.uk. All rights reserved. No part of IASB's publications may be translated, reprinted or reproduced or utilized in any form either in whole or in part or by any electronic, mechanical or other means, now known or hereafter invented, including photocopying 
and recording, or in any information storage and retrieval system, without prior permission in writing from the International Accounting Standards Committee Foundation. The IASB Framework for the Preparation and Presentation of Financial Statements is reproduced in this book and published by Palgrave, with the permission of IASCF. The approved text of the International Accounting Standards is that published by IASB in the English language and copies may be obtained direct from IASB at the address above. The IASB logo/Hexagon Device, IAS, IASB, IASCF, IASC and International Accounting Standards are Trade Marks of the International Accounting Standards Committee Foundation and should not be used without the written approval of the International Accounting Standards Committee Foundation.

Every effect has been made to contact all the copyright-holders, but if any have been inadvertently omitted the publishers will be pleased to make the necessary arrangement at the earliest opportunity. 


\section{List of Abbreviations}

$\begin{array}{ll}\text { AAA } & \text { American Accounting Association, USA } \\ \text { AARF } & \text { Australian Accounting Research Foundation } \\ \text { AG } & \text { Aktiengesellschaft, Germany } \\ \text { AICPA } & \text { American Institute of Certified Public Accountants } \\ \text { ASB } & \text { Accounting Standards Board, UK } \\ \text { ASC } & \text { Accounting Standards Committee, UK } \\ \text { ASSC } & \text { Accounting Standards Steering Committee, UK } \\ \text { BADC } & \text { Business Accounting Deliberations Council, Japan } \\ \text { CICA } & \text { Canadian Institute of Chartered Accountants } \\ \text { CNC } & \text { Conseil National de la Comptabilité, France } \\ \text { CNNC } & \text { Compagnie Nationale des Commissaires aux Comptes, France } \\ \text { COB } & \text { Commission des Opérations de Bourse, France } \\ \text { CPA } & \text { Certified Public Accountant, USA } \\ \text { CRC } & \text { Comité de Réglementation Comptable, France } \\ \text { DRS } & \text { Deutscher Rechnungslegungs Standard (German accounting } \\ & \text { standard) } \\ \text { DSOP } & \text { Draft statement of principles } \\ \text { DSR } & \text { Deutsche Standardisierungsrat (German Standardization Council) } \\ \text { ED } & \text { Exposure draft } \\ \text { EITF } & \text { Emerging Issues Task Force, USA } \\ \text { EU } & \text { European Union } \\ \text { FASB } & \text { Financial Accounting Standards Board, USA } \\ \text { FAS } & \text { Financial Accounting Standard, USA } \\ \text { FDI } & \text { Foreign direct investment } \\ \text { FRS } & \text { Financial Reporting Standard, UK } \\ \text { GAAP } & \text { Generally accepted accounting principles } \\ \text { GoB } & \text { Gründsätze ordnungmässiger Buchführung (Principles of orderly } \\ \text { HGB } & \text { book-keeping) } \\ \text { IASB } & \text { International Accounting Standards Board } \\ \text { IASC } & \text { International Accounting Standards Committee } \\ \text { IAS } & \text { International Accounting Standard } \\ \text { ICAEW } & \text { Institute of Chartered Accountants in England and Wales } \\ \text { IdW } & \text { Institut der Wirtschaftsprüfer, Germany } \\ & \end{array}$


IFAC International Federation of Accountants

IOSCO International Organization of Securities Commissions

JICPA Japanese Institute of Certified Public Accountants

KK Kabushiki kaisha

MNE Multinational enterprise

NYSE New York Stock Exchange

OECD Organization for Economic Cooperation and Development

OEC Ordre des Experts Comptables, France

PCG Plan Comptable Général, France

PLC Public limited company, UK

R\&D Research and development

SA Société anonyme, France

SEC Securities and Exchange Commission, USA

SEL Securities and Exchange Law, Japan

SSAP Statement of standard accounting practice, UK

STRGL Statement of total recognised gains and losses

UNCTAD United Nations Conference on Trade and Development

UN United Nations

US GAAP US generally accepted accounting principles 